\title{
Fatal predation of oilfish, Ruvettus pretiosus (Gempylidae), by a young short-finned pilot whale, Globicephala macrorhynchus (Delphinidae)
}

\author{
María del Carmen García-Rivas ${ }^{1}$, Juan J. Schmitter-Soto ${ }^{2}$ and Jonathan Pérez-Flores ${ }^{3}$ \\ 1. Comisión Nacional de Áreas Naturales Protegidas, Av. Insurgentes s/n, 77000 Chetumal, Mexico; mcgarcia@conanp.gob.mx \\ 2. El Colegio de la Frontera Sur, Mexico; jschmitt@ecosur.mx \\ 3. Africam Safari, Mexico; johnspf77@yahoo.com.mx
}

Received 15-II-2013 Corrected 8-IV-2013 Accepted 24-IV-2013

\begin{abstract}
We found a dead whale (Globicephalus macrorhynchus) whose probable cause of death was an internal injury produced by a $1 \mathrm{~m}$-long oilfish ( $R u$ vettus pretiosus) that had bitten the whale's stomach from the inside. This is the first record of an oilfish in Mexican Caribbean waters.
\end{abstract}

\section{KEY WORDS}

Marine mammals, mesopelagic fishes, feeding behavior, new records, Caribbean sea

\section{RESUMEN}

Describimos un intento fatal de depredación de un escolar, Ruvettus pretiosus, por un joven calderón de aletas cortas, Globicephala macrorhynchus. Éste es el primer registro de un escolar en aguas del Caribe mexicano.

\section{PALABRAS CLAVE}

Mamíferos marinos, peces mesopelágicos, conducta alimenticia, nuevos registros, mar Caribe
The ecological interaction between large mesopelagic fish and small odontocetes is often assumed to be based on competition. For example, the oilfish Ruvettus pretiosus Cocco (1833) and the short-finned pilot whale Globicephala macrorhynchus Gray (1846) occur together and use the same resources: they both prey on squid and fish (Overholtz \& Waring, 1991; Vasilakopoulos, Pavlidis \& Tserpes, 2011). The oilfish is mesopelagic; it ranges between 100 and $800 \mathrm{~m}$ deep, but it is more common not deeper than 400m (Nakamura \& Parin, 1993). Pilot whales can dive up to $500 \mathrm{~m}$ or more (Baird, Borsani, Hanson \& Tyack, 2002).

Globicephala macrorhynchus is common in the Caribbean. Ruvettus pretiosus occurs worldwide in tropical and temperate seas, although this fish is rarely recorded in the Caribbean (Claro, 1994).

Although competition between these species could be expected, predation by the odontocete on the oilfish is also possible, given the difference in size. However, attacking a large fish entails a hazard for the whale. Apparent teaching by experienced, older individuals has been documented repeatedly in cetaceans; this effort ensures safety during the acquisition of hunting skills (Boran \& Heimlich, 1999).

The objective of this short contribution is to present and discuss a case of probable attempted predation by a young short-finned pilot whale on an oilfish.

On April 26th, 2009, around 17:30h, a dead short-finned pilot whale was found on the beach at Puerto Ángel, $8 \mathrm{~km}$ south of the port of Mahahual, Caribbean coast of Mexico $18^{\circ} 37^{\prime} \mathrm{N}, 87^{\circ} 44^{\prime} \mathrm{W}$. The following day, a necropsy was performed on the site.

The cetacean was a $2,94 \mathrm{~m}$ long male (Fig. 1). This is likely a young individual, since males in this species usually attain sexual maturity at a minimum length of $3,20 \mathrm{~m}$ (Kasuya \& Marsh, 1984).

The probable cause of death was an internal injury produced by a $1 \mathrm{~m}$-long specimen of oilfish (Fig. 2), which had bitten the stomach of the whale from the inside. The 


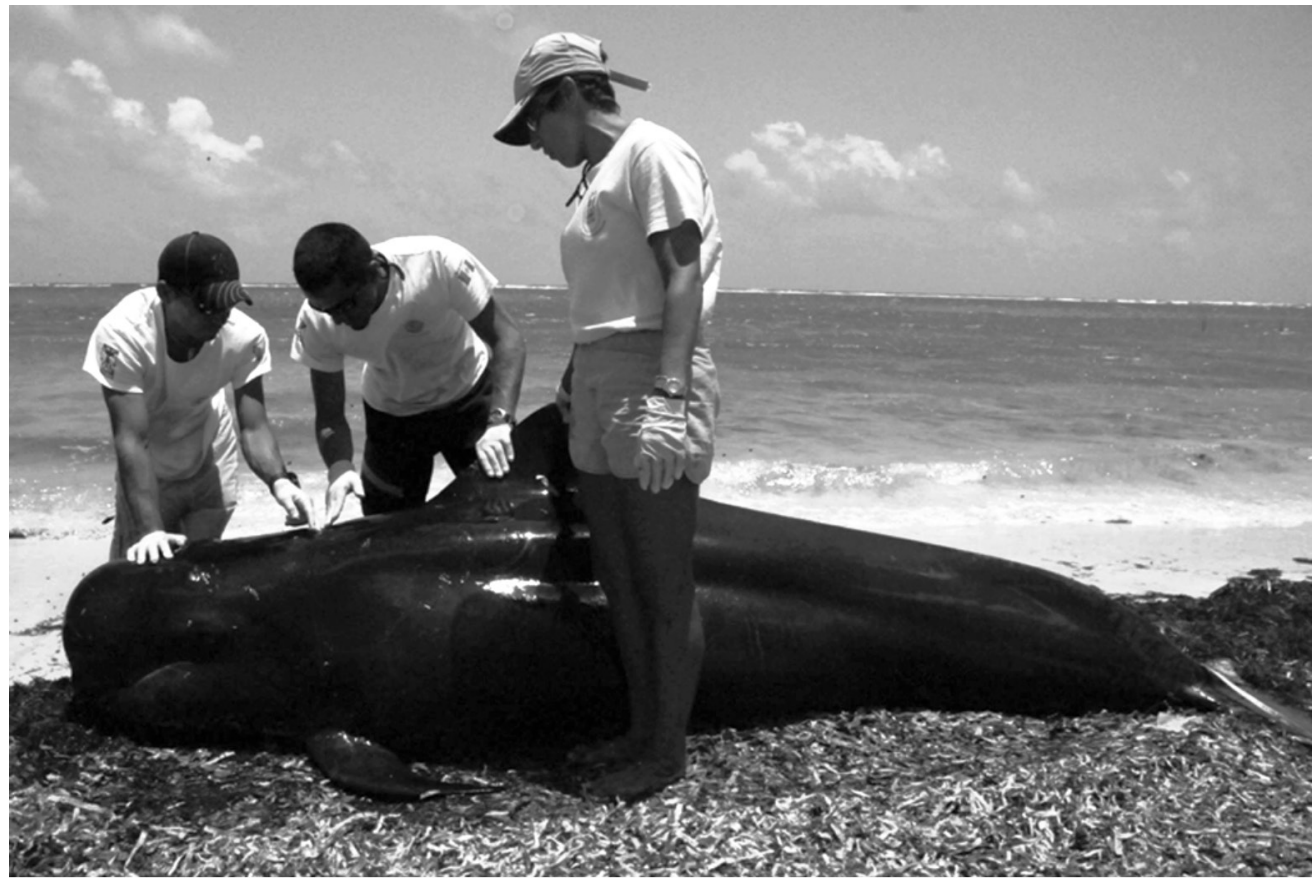

FIG. 1. Globicephala macrorhynchus, a young male, 2,94m long, dead on the beach in Puerto Ángel, Mexican Caribbean, just before the necropsy.

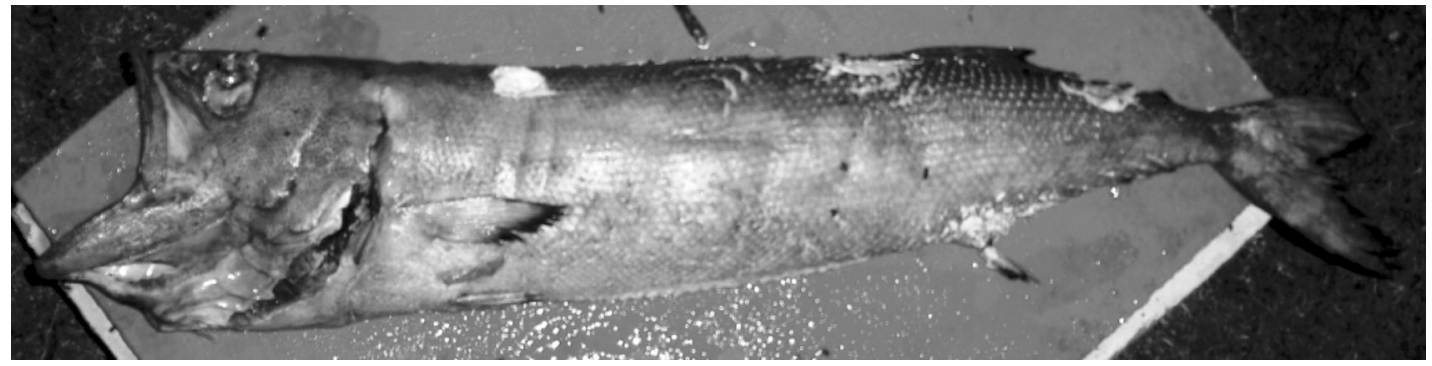

FIG. 2. Ruvettus pretiosus (ECOCH 6333), $1 \mathrm{~m}$ long, extracted from the mouth and stomach of a dead young male Globicephala macrorhynchus in Puerto Ángel, Mexico.

whale also suffered two traumatisms near the head and some lacerations on the body, probably from thumping against a reef (either the extant reef barrier, or a deep-water fossil reef) while struggling with the fish. Otherwise, the specimen displayed good body condition, without symptoms of any malady.

Short-finned pilot whales are gregarious; according to local residents, there were other individuals in the water near the area at the time of the stranding. Perhaps the fatal attempted predation of this large oilfish was due to inexperience of the young whale.
Pilot whales prefer to feed on deep-water squid off the continental shelf (Mintzer, Gannon, Barros \& Read, 2008), which in the stranding area occurs at less than $1-2 \mathrm{~km}$ from the coast. It is presumed that the encounter occurred in this zone.

This is the first record of an oilfish in Mexican Caribbean waters; the only gempylids previously known from the area were Gempylus serpens Cuvier (1832) and Nesiarchus nasutus Johnson (1862) (Schmitter-Soto et al., 2000). The oilfish had been recorded before in Mexican waters of the Atlantic, but only in the Gulf of Mexico (McEachran 
\& Fechhelm, 2005); in the Caribbean it is known at least from Belize (Claro, 1994), Guadeloupe (Froese \& Pauly, 2011), Puerto Rico (Erdman, 1961), and Venezuela (Cervigón, 1994).

A second oilfish was recently captured about $150 \mathrm{~m}$ deep by a long-line fisherman on February 2013 off Banco Chinchorro, ca. $30 \mathrm{~km}$ west of where the attempted predation discussed here occurred. This specimen, 1,20 m long, was not preserved, but it was thoroughly explored for parasite helminths (D. González-Solís, pers. comm.).

The skeleton of the pilot whale is on exhibition at the offices of the Parque Nacional Arrecifes de Xcalak (National Park Xcalak Reefs, part of the Mexican official protected areas network), whereas the oilfish, fixed in formalin, is preserved and catalogued (ECOCH 6333) in the ichthyological collection of ECOSUR at Chetumal, Mexico.

\section{ACKNOWLEDGMENTS}

The Mexican Procuraduría Federal para la Protección del Ambiente (Federal Attorney for Environmental Protection) granted permission to study and keep the specimens. L. Amezcua and F. León helped perform the necropsy. J. Padilla helped prepare the figures.

\section{REFERENCES}

Baird, J., Borsani, F., Hanson, M.B. \& Tyack, P.L. (2002). Diving and night-time behavior of long-finned pilot whales in the Ligurian Sea. Marine Ecology Progress Series, 237, 301-305. Retrieved from http://www.int-res.com/abstracts/meps/ v237/p301-305/

Boran, J.R. \& Heimlich, S.L. (1999). Social learning in cetaceans: hunting, hearing and hierarchies. In H.O. Box \& Gibson K.R. (Eds.), Mammalian social learning: comparative and ecological perspectives (282-307). Cambridge: Cambridge University Press. Retrieved from http://books.google.es

Cervigón, F. (1994). Los peces marinos de Venezuela. Volume 3. Caracas: Fundación Científica Los Roques. Retrieved from http://books.google.es

Claro, R. (Ed.). (1994). Ecología de los peces marinos de Cuba. Chetumal: Academia de Ciencias de Cuba/Centro de
Investigaciones de Quintana Roo. Retrieved from http:// books.google.es

Erdman, D.S. (1961). New fish records and one whale record from Puerto Rico. Caribbean Journal of Science, 1, 39-40.

Froese, F. \& Pauly, D. (Eds.). (2011). FishBase. Retrieved from www. fishbase.org

Kasuya, T. \& Marsh, H. (1984). Life history and reproductive biology of the short-finned pilot whale, Globicephala macrorhynchus, off the Pacific coast of Japan. Reports of the International Whaling Commission 6, 259-310. Retrieved from http://www.helenemarsh.com/publications/JournalPapers/1984/KasuyaMarshLifeReproPilot1984.pdf

McEachran, J.D. \& Fechhelm, J.D. (2005). Fishes of the Gulf of Mexico. Volume 2: Scorpaeniformes to Tetraodontiformes. College Station: University of Texas Press. Retrieved from http://books.google.es

Mintzer, V.J., Gannon, D.P., Barros, N.P. \& Read, A.J. (2008). Stomach contents of mass-stranded short-finned pilot whales (Globicephala macrorhynchus) from North Carolina. Marine Mammal Science, 24, 290-302. doi:/10.1111/j.1748-7692.2008.00189.x/full

Nakamura, I. \& Parin, N.V. (1993). FAO species catalogue. Vol. 15. Snake mackerels and cutlassfishes of the world (families Gempylidae and Trichiuridae). An annotated and illustrated catalogue of the snake mackerels, snoeks, escolars, gemfishes, sackfishes, domine, oilfish, cutlassfishes, scabbardfishes, hairtails, and frostfishes known to date. FAO Fisheries Synopses, 125, 1-136. Retrieved from http:// books.google.es

Overholtz, W.J. \& Waring, G.T. (1991). Diet composition of pilot whales Globicephala sp. and common dolphins Delphinus delphis in the mid-Atlantic bight during Spring 1989. Fishery Bulletin, 89, 723-728. Retrieved from http://nero.noaa. gov/prot_res/atgtrp/ai/bgl/5.pdf.

Schmitter-Soto, J.J., Vásquez-Yeomans, L., Aguilar-Perera, A., Curiel-Mondragón, C. \& Caballero-Vázquez, A. (2000). Lista de peces marinos del Caribe mexicano. Anales del Instituto de Biología de la Universidad Nacional Autónoma de México, Serie Zoología, 71, 143-177. Retrieved from http://www. ejournal.unam.mx/zoo/071-02/ZOO71204.pdf

Vasilakopoulos, P., Pavlidis, M. \& Tserpes, G. (2011). On the diet and reproduction of the oilfish Ruvettus pretiosus (Perciformes: Gempylidae) in the eastern Mediterranean. Journal of the Marine Biology Association of the United Kingdom, 91, 873-881. doi 10.1017/S0025315410001785. 
